\title{
Christian hospitality in Javanese bancaan tradition
}

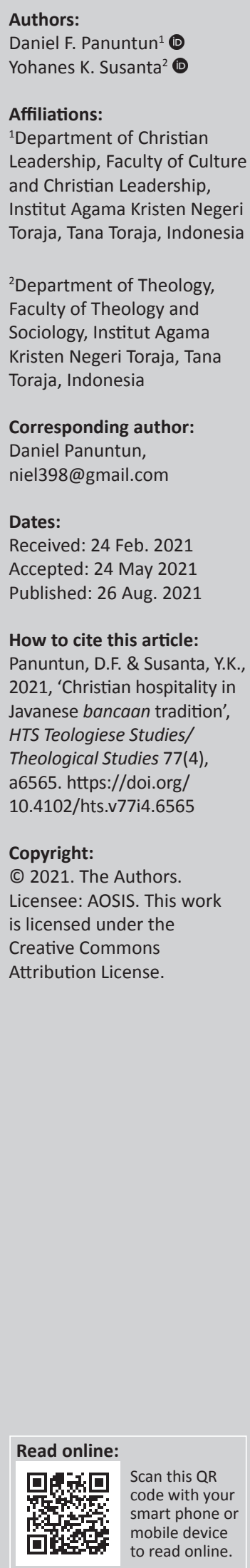

Javanese people have unique characteristics and traditions that make them appealing for research. One of the unique things of the Javanese tradition called bancaan is that it is aimed at appreciating children. Bancaan is a simple banquet of gratitude on the occasion of a child's birthday by inviting their playmates to pray together for their good. This tradition is rich in the value of hospitality but began to disappear as influences of current development overtake. Given this reality, this study discovered Christian values of hospitality in the bancaan tradition. This discovery is based on a survey by Lee Roy Martin and Michele Hersberger. This research is based on the paradigm of qualitative research. Data collection was conducted by examining the literature and studying the Bible. The problem was analysed using interactive analysis, revealing Christian hospitality values in the bancaan tradition. The values showed are as follows: (1) bancaan is open to everyone in nature despite their backgrounds, (2) bancaan is a form of interaction of hospitality in simplicity and (3) bancaan is a form of regeneration of hospitality values to the child.

Contribution: This manuscript provided an overview of one form of Javanese culture, which was then linked to the principles of hospitality from Jesus. This culture was a form of Javanese culture towards children's appreciation. It is hoped that this manuscript contributes to the preservation of Javanese bancaan culture.

Keywords: hospitality; Javanese tradition; bancaan; Christianity; inclusion; children.

\section{Introduction}

Indonesia is a country blessed with its diversity of ethnicities. Each ethnicity in Indonesia has its variety of specialities forming its prominent characteristics and strengths. This diversity in each race's principal characters and powers makes Indonesia a unique nation whose people's strength of character is not easily distinguishable (Wijayanti \& Nurwianti 2010:120). Indonesia is rich in ethnic diversity. One of them is the Javanese ethnic group (people), which is quite strong in Indonesia's culture. With its variety of unique characteristics, the Javanese has been studied by numerous scholars and became a point of interest to science a long time ago (Melalatoa 1995). Javanese people are part of ethnicities in Indonesia that has fascinating characteristics to study.

Famous ethnographers such as Clifford Geertz and Hildred Geertz were very much interested in delving into the Javanese culture, resulting in research providing a picture of the Javanese social structure, life and habits (Clifford 1983). Javanese people have a series of exceptionally rigid rules that must be obeyed. These rules were composed of written and unwritten rules. The unwritten ones are generally called unggah-ungguh, which is a tradition containing Javanese customs and values. The Javanese value modesty and humility, for example, the politeness of one who speaks of Javanese language to others, ares influenced by the Javanese culture (Sarwanto 2013:176-177). Javanese people is a society that is rich with fascinating traditions, habits, customs and language systems and is an essential subject of study in the research field given its cultural wealth is also derived from its significant population in Indonesia.

Research reveals many culturally rich Javanese traditions, from birth to death. The Javanese is an ethnic group rich in practices in which many of them are mystical. Even so, there are unique traditions, a ritual in nature, aimed at Javanese children. The hospitality value of Javanese people can be perceived in traditions aimed at appreciating children. Javanese people are an ethnic group that puts particular emphasis on the appreciation of infants and children. The appreciation itself is manifested in several traditions or rituals exclusive to children. Several kinds of research that prove the child's appreciation are Brokohan (Safitri 2018:4), and neloni, mitoni and tingkeban rituals (Adriana 2011:239). Another Javanese tradition is bancaan, detailed by Lailiyah and Pradanta, Sudardi and Subiyantoro (2015). The tradition is conducted to express gratitude for the birth weton (Pradanta et al. 2015:155). Weton itself is the person's birthday in the Javanese calendar. It 
falls every 35 days, a duration called selapan in Javanese (Lailiyah, Waryanti \& Agan 2018:2). Weton itself is a calculation of the day that is typical of the Javanese. This is adjusted to the Javanese calendar. Weton is usually used to walk a good day and one of them is in the bancaan tradition. The bancaan tradition itself is calculated based on the weton of the child and is celebrated until the child is considered to have entered adolescence. The focus of the Javanese tradition that will be discussed is the tradition of appreciating children, namely bancaan.

Bancaan is a form of Javanese local wisdom rich in hospitality values. Local wisdom cannot be separated from its people's cultures. It is local knowledge in nature that means that the experience merges with the existing system in the community covering norms, beliefs and culture and then expressed on forms of habits performed by the community such as traditions and myths internalised for an extended period (Dokhi et al. 2016:8). Local wisdom has an essential meaning as the cultural wealth of the Indonesian nation. Moreover, it also has a significant value of historicity and diversity owned by Indonesia.

Appreciation of children like this is also often applied in various ethnicities worldwide, with one of the examples being the Jewish people. The Bible also records various acts of appreciation of children; the story of Samuel who was offered to Eli in Shiloh and the level of Jesus presented at the Temple at 12 years of age being examples in both Old and New Testaments. These things show the existence of a unique appreciation of children. Appreciation of children was also often conducted by Jesus whenever he met with children. One example is when he blessed children coming to him after his disciples rebuked the said children. The similarities of children appreciation between Javanese and Jewish people can be a fascinating study. Even though these two groups use different forms of gratitude, they share similar meaning about children's distinction and appreciation.

Cultural values to children appreciation full of hospitality, especially within Indonesian culture, had begun to erode because of the Big Data culture associated with global changes brought by Industrial Revolution 4.0. This fourth phase of the Industrial Revolution is unique as it has the nature of 'disruption' in every way of life, including being in the sociocultural area (Prasetyo \& Trisyanti 2018:24). The changes also significantly influence children born within the AlphaGeneration era, so that a model of worship to preserve children's faith in God is necessary (Panuntun et al. 2019:193). This disruption movement has brought automation and industrial advancement interconnection, eroding Indonesia's socio-culture and religious traditions. Javanese people, both parents and children, began to forget the bancaan tradition by replacing it with a more millennial tradition according to the context of the era. Children are also more likely to follow the era and forget Javanese traditions such as bancaan. The era of big data affects the mindset of Javanese children and encourages them to leave Javanese traditions. Reflecting on that, efforts to preserve and protect cultures based on
Indonesian people's local wisdom are necessary, especially for Javanese bancaan tradition. These efforts need to be performed by Christians as God's people created as creatures of culture.

This study focusses on the culture of appreciation to children, similar to research by Herwinesastra with the specific topic of Betangkant Anak culture as the contextualisation effort to communicate Christ to all Dayak Keninjal tribesmen (Herwinesastra 2019:199). Studies of similar inspiration include research by Siswanto on Javanese people in the form of a contextual approach between Eastern Javanese tradition and the Gospel. It stressed the importance of the contextual approach between practice and the Gospel (Siswanto 2017). The findings of the two studies are to explain Christianity in efforts to preserve local wisdom. Both bentangkan anak culture and traditions in East Java have in common that through these cultural points and associated with Christian values can be used to preserve existing cultures and communicate Christian values. These two studies will be the basis for communicating the culture of bancaan and Christian values of appreciating children. Bancaan tradition is a manifestation of the Javanese culture of appreciation to children, which is unique to the Javanese people and strongly relates to Jesus. He said that we have to become like children to enter the kingdom of heaven as in Matthew 18:3. The two ideas of appreciating children can be deconstructed to reveal the noble values of bancaan as an appropriate tradition that supports the nurture of Christians of Javanese descendent. It will also create a hospitality lifestyle amongst Javanese Christians, similar to the Nazirite lifestyle for preachers (Haryono \& Panuntun 2019). This kind of deconstruction can be utilised as a relevant form of contextual approach that strives to preserve the originality of the Javanese culture of hospitality.

Based on the background and on the loss of appreciation for children and the equality of respect for children by Jesus, the study's focus is based on a single problem statement on how the Christian hospitality values between the reflection of bancaan as a form of children appreciation tradition in Javanese people and the topic of Jesus blessing the children. This research aims to reveal relevant Christian hospitality values between the reflection of bancaan as a form of children appreciation tradition in Javanese people and the topic of Jesus blessing the children. The research is expected to give several benefits: (1) providing a review of the richness of hospitality values and characteristics of Javanese tradition, especially bancaan, (2) preserving Javanese tradition of bancaan as a part of the Christian tradition of Javanese people, (3) giving recontextualisation of meaning to bancaan so that an appropriate contextual approach may be produced for the development of Javanese Christians and (4) acting as a means to communicate Christ to Javanese people of present times.

\section{Methods}

This research is based on the paradigm of qualitative research (Adimihardja 2011). The interactive analysis model is used in this research, which is a form of analysis with a working 
order of data collection, data reduction and conclusion drawing. Data collection was conducted by examining the literature and studying the Bible. First, the researchers collected data on bancaan tradition through books and research journals. Then, the researchers conducted a Bible study on the topic of Jesus blessing children. After that, reviews of literature from experts regarding hospitality values were shown. The resulting data collected were then reduced to conclude each category through interactive analysis. The interactive analysis is an analysis introduced by Miles and Huberman. The stages of this analysis consist of data collection, data condensation, data display and data interpretation (Miles, Huberman \& Saldaña 2014). In this study, the authors will collect data, formulate condensation data in a table and then explain various findings based on library data. The final step is to interpret the data or draw conclusions. Conclusion drawing from each type based on interactive analysis is used to organise a model of relevant and contextual Christian hospitality values between reflections of bancaan tradition as a tradition aimed at appreciating children in Javanese people and the topic of Jesus blessing children.

\section{Results and discussion Bancaan tradition}

Indonesians, especially Javanese, have several forms of expression as a form of tranquillity and gratitude to God. These expressions are manifested in various states of Javanese-styled ceremonies and traditions. The Javanese still conduct these traditions to preserve their customs and culture. One of these is bancaan weton. Some Javanese do this to express gratitude to God on birthday commemorations in the Javanese calendar for all blessings incurred (Lailiyah et al. 2018:4). This heavenly gratitude underlies Javanese hospitality values.

The bancaan tradition is one of the local wisdoms that need to be preserved in Indonesia. As a form of local wisdom, bancaan has several local features: (1) it is able to withstand foreign cultures, (2) it has capacities in accommodating elements of foreign culture, (3) it has abilities in terms of integration of foreign culture to the native culture, (4) it has degrees in terms of control and (5) it is able to guide themselves to the progress of times. By looking at these characteristics, it can be inferred that local wisdom is a cultural product that can differentiate one local community from others (Lailiyah et al. 2018:4). The bancaan tradition is Javanese local wisdom that needs particular attention given the various cultural wealth contained within it.

Studies on the bancaan tradition were conducted by Pradanta et al. (2015) at Surakarta and Lailiyah at Nganjuk regency. Surakarta is a city that still preserves Javanese culture. Surakarta and Yogyakarta are heirs to the Mataram Kingdom. Places of Javanese cultural heritage apparent in this city include Karaton Kasunanan Surakarta (Royal Palace of the Surakarta Sunanate) and Pura Mangkunagaran (Palace of Principality of Mangkunagara) (Pradanta et al. 2015:159).
Research by Lailiyah took place in Jekek village, Termas sub-village, Baron sub-district, Nganjuk regency and East Java province (Lailiyah et al. 2018:9). By looking at the places where the above-mentioned research took place, it can be inferred that bancaan is performed by Javanese people, especially those in Central and East Java.

Bancaan is a tradition of the commemoration of birthday called weton based on Saptawara (seven-day week naming system) and Pancawara (five-day week naming course) of the Javanese calendar that has become a tradition for Javanese people. The wetonan cycle of the Javanese calendar lasts for 35 days. Thus unlike normal birthday commemoration held annually, the practice requires remembrance every 35 days. The tradition itself is performed as an expression of gratitude to the Supreme Being, in which prayers were held so that the person commemorated (dibancaki) is safe from any danger, present or future, and is successful in his or her endeavours. In essence, bancaan acts as a form of balance for the child commemorated. This 'balance' covers corporeal and spiritual harmony and also harmonic and synergic balance. Each child marked with bancaan is believed to be later spared from carelessness and mala or dangers (Pradanta et al. 2015:157). Bancaan is a noble and essential tradition forming unique traits of Javanese people. This tradition is a form of simple selametan (gratitude ceremony) for the child.

Bancaan has the proper form of expressing gratitude merely. This expression of appreciation is performed by inviting playmates of the child commemorated to participate together in a simple celebration. Children will be coming in the flock to visit and celebrate their friend's birthday in an atmosphere full of simplicity. The things prepared for bancaan are called uba rampe. Uba rampe designed is not haphazard, with each item containing special meanings. Some of the $u b a$ rampe prepared are as follows (Pradanta et al. 2015:161-65):

- Tumpeng nasi putih [cone-shaped white rice] The cone-shaped (tumpeng) white rice symbolises a mountain, which means that humans' prayers go up to heaven by looking at the shape of the tumpeng.

- Ingkung [whole chicken] Ingkung is a chicken prepared whole and served whole too. Ingkung is usually placed in the centre, next to the tumpeng. The symbolisation lies within the name, a play of the Javanese phrase ingsung tansah manekung, meaning that humans are always in prostration (deference) in pleading to God.

- Tebu [sugarcane]

Similar to ingkung, sugarcane's symbolisation lies within its name, a play of the Javanese phrase anteping kalbu, meaning steadiness of the heart. It can be understood as the steadiness of the heart in pleading to God.

- Gudangan or kuluban Gudangan is a traditional dish that consists of various steamed vegetables. Each vegetable has its own symbol, such as bayem [spinach], which symbolises tranquillity (adem ayem), kacang dawa [long beans] symbolises long life (yuswa dawa), cambah [bean sprouts] symbolises spreading 
goodness as a Javanese people (tansah semambrah), kluwih [breadnut] represents an abundant life and kangkung [water spinach] represents an expression of expectation of perpetual protection by the Almighty God (jinakungan dening Gusti Kang Murbeng Dumadi). This gudangan or dish of boiled vegetables in its entirety can be understood as having a meaning that if life is passed in tranquillity with each other, then humans can live longer and abundantly, develop and protected by the One Almighty God.

- Boiled egg

The number of boiled eggs served in bancaan tradition is mostly 7, 11 or 17 . Each of those numbers has its meaning: the number seven (pitu) symbolises pitulungan or help, the number 11 (sewelas) symbolises kawelasan or mercy and the number 17 (pitulas) combines the symbolism of the two numbers above into pitulungan and kawelasan or help and compassion. The eggs boiled usually come from ayam Jawa (ayam kampong, a chicken breed native to Java), which left unpeeled during the presentation. However, presently the eggs can come from chicken of any species. Uniquely, in serving of these boiled eggs, they are not filled in whole but are divided into several portions at first so that more people can enjoy them.

- Bumbu urap or sambel gudangan (seasoning of gudangan) The vegetables served in bancaan are only boiled and then given seasoning, called bumbu urap or sambel gudangan. It is composed of grated coconut added with garlic, shallot, coriander, bay leaf, lime, lemongrass, brown sugar and salt, all to taste.

- Jajanan pasar (Javanese snacks)

Jajanan pasar consists of various Javanese traditional snacks, which is commonly sold in traditional markets, such as wajik, symbolises courage of doing good ('wani tumindak becik'); gedhang ijo (green banana), symbolises a necessity to do the best for happiness of a family, spouse and children ('gaweo seneng anak lan bojo'); sukun (breadfruit, usually cut and fried), symbolises harmony ('rukun'); nanas (pineapple), symbolises avoiding greed ('wong urip aja nggragas'); dhondong (June plum), symbolises avoiding talking too much ('ojo kegedhen omong'); jambu (guava), symbolises refraining from bad deed ('ojo ngudal barang sing wis mambu') and jeruk (orange), symbolises pursuing unity in physical and spiritual life ('jaba jero kudu mathuk'). In general, the jajanan pasar gives meaning that if humans follow God and his rules in life, they would not go astray. In Javanese, it is expressed in the following: rup yen dasar tatanane Gusti tentu ora bakal nyasar.

- Kembang setaman (a set of flowers considered sacred in Javanese culture)

Kembang setaman is composed of mawar merah (red rose), mawar putih (white rose), kanthil (white champaca), melati (jasmine) and kenanga (ylang-ylang). Each of them has its meaning: mawar is a play for awar-awar purpose that it is there for the person commemorated to avoid negative lust; melati is a play for melat-melat ning ati, meaning that it is there for the person marked always to be careful and vigilant; kanthil is a play for tansah kumanthil, meaning that the heart of the person commemorated is expected to be permanently linked to the ancestors and parents so that she or he becomes an obedient child for them.

- Bubur 7 rupa (seven types of porridge)

Bubur 7 rupa's main ingredients are white, or savoury, porridge and red, or sweet, porridge. It gives the meaning as a pepeling (caution) in order not to be a disobedient child.

- Coins

Coins are put under the tumpeng or the banana leaf underneath it. It symbolises that everyone, when reaching adulthood, should not glorify money or consider it everything they need. Javanese people's focus is prosperity and well-being with nature, which is their definition of a successful life.

Bancaan weton is an important traditional symbol for the Javanese religious belief from how Javanese people understand it. Bancaan is a simple tradition; although the $u b o$ rampe provided is quite many, it can be fulfilled by all Javanese people who want to carry out this tradition. This is because even though it is complicated, it is a material that is easily available and cheap. This cheap material can be seen from the eggs that have to be divided so that everyone obtains it. Bancaan also has many complex symbols but can be captured and accepted by children from the description of the food the children get. The depiction of these simple symbols will stick to the child's mind and give the impression of a life filled with simple but still appreciated. Bancaan weton expresses moral and spiritual values that become the guiding light of Javanese people. Expression of the symbols in bancaan weton is apparent in the understanding of all its ubo rampe. Bancaan is performed to offer ubo rampe of food to others and give meanings and expectations to the children commemorated with bancaan. Symbols of all the bancaan's ubo rampe become an effective way of communication for Javanese people in expressing their hopes to their children. This is a tradition of Javanese simplicity in the occasion of gratitude by inviting their playmates. It is also a simple practice full of gratitude with ubo rampe or foods served in an atmosphere full of clarity.

\section{Jesus blessing the children}

Jewish people are God's chosen people. The term Jewish etymologically emerged from the word Judah, which is used to represent religion and ethnicity. Jewish people comprise a social group whose life is intertwined with their experience in their various exiles. The Jews have the only character in which they establish their claim as God's chosen people about their religion and race (Samsuri 2004:1-3). For almost 3000 years, these people do not have their land, but peculiarly, this nation can preserve their ethnic identity and survive amidst other great countries.

In the New Testament world, when Jesus began his work, it seems that there was less appreciation for children. This is 
because everyone tried to do something important during the Roman ruling era so that children who were not from prominent people would be left alone (Green \& Mcdonald 2013:184). The respect for children in the New Testament world is not too heeded; however, the Bible records various things that happen related to respect for children. An example of Jesus blessing children is found in Matthew 19:13-15. The narration described the scene of Jesus blessing the children and saying that they belong to the kingdom of heaven. Based on its background writing, Matthew's Gospel was chosen that sought to express why Jesus came to this world as a great King and Messiah that Israelite has been longing to see for centuries. The Gospel was written for the Jewish people in every nation in conjunction with the tradition often performed by Jewish people at present. This scene can be associated with the Jews practice at that time (Haryono 2015). The study of Jesus blessing the children is a form of Christian values referring to the appreciation of children that must be preserved in the present time.

The narration of Jesus in verse 13 (ESV) reads 'Then children were brought to him that he might lay his hands on them and pray. The disciples rebuked the people', which shows that the children presented to Jesus were approximately aged 1-2 years so that Jesus could lay his hands on them and blessed them. It is speculated that the children were presented to Jesus by their parents, families or relatives so that the children could come and see Jesus in person. It is a good deed if we come to Jesus like these children. Presenters of the children expected Jesus to lay his hands on the children, reflecting the habits and customs of blessing by a father to his children in Jewish tradition. This kind of practice was performed when Jacob blessed his son, Joseph (Henry 2000:394-95). Looking at the interpretation, Jesus gives heavy emphasis on appreciating their children. However, problems arose when Jesus' disciples showed contradicting attitude by rebuking the people who presented their children to him. This is because the child's position at that time was deemed less critical, mainly because of the influence of colonialism from Rome, so it is better if those who are talking about important things and involving Jesus are adults, not children. Children are considered trivial, which is why Jesus' Disciples forbade these children to go to Jesus.

Verse 14 (ESV) said: 'but Jesus said, "Let the little children come to me and do not hinder them, for to such belongs the kingdom of heaven"', meaning that Jesus stressed that to enter the kingdom of heaven, one should not rely on their works alone. Here Jesus also gave a picture in which the children around him will inherit the kingdom of heaven. People should know that the kingdom of heaven is not acquired by deed but needing 'help' and 'being dependent' or vulnerable like the little children who will enter the kingdom of heaven. There is no place for humans who thought of eternal life or heaven's kingdom can be obtained through human wisdom or good deeds. The hospitality that Jesus gave is regardless of the background of the children from rich families or not. All children are entitled to an award.
Despite the great tendency of these children to come from ordinary families, this can be seen from the response of Jesus' disciples when they rejected the children. Jesus also saw the form of faith of these children. Every child who wanted to have a relationship with Jesus had to have a foundation of faith in Jesus at least. Jesus stressed that all of the things above are gifts from his relationship with the children. Jesus gave an example of hospitality to everyone, including putting little children as the priority. Hospitality values should be given to small children from now so that every child can have a high hospitality spirit.

\section{Values of hospitality}

Hospitality is a form of friendship that is a tradition having Christian values practised for centuries. It is a manifestation of God's love to the world implemented by Christians. Every person feeling God's love will always have hospitality (Martin 2014:1). Hospitality can also be called a form of extension of God's love to this world. Believers are expected to have a lifestyle of hospitality as fellow workers of God for this world. They are not building barriers or walls of partition based on ethnicities, religions, beliefs and races. Still, hospitality can open up and accept all people in this world regardless of their cultural background. The Church should have an attitude of hospitability in building a form of relationship with other cultures without violence.

Hospitality is an essential value for humans to be able to survive and thrive in present times. Forms of hospitality can be found in various situations, including in nomadic living where lodgings exist. The host can listen to these wayfarers' stories and the wayfarers themselves can rest for their survival. It is a practice of hospitality. Hospitality teaches humans to receive others. The meaning of hospitality itself is composed of the words 'love' and 'strangers'. Thus, the relationship of hospitality is a form of love for everyone (Hershberger 2009). Hospitality is an important thing that can be understood to be love for each human in this world. The hospitality of the Christians will always bring the light of God's love to this world.

Hospitality also has its own risk. It can be manifested in a breaking-in by strangers as a fruit of the host's goodwill. The cordial acts themselves can also be easily misused. These risks become a severe study of hospitality. According to Susanta, hospitality troubles can be solved for each human ever loyal to perform hospitality to achieve harmony (Susanta 2015:306). Hospitality should always be performed by every Christians regardless of the risks it may pose. Hospitality, if loyally served, will guarantee peace and tranquillity and remove those risks.

Research by Lee Roy Martin produced a form of Christian hospitality. The model of hospitality in the Old Testament becomes the guideline of hospitality practices in a multifaith community. This kind of hospitality is based on several things: (1) each person has the image of God within them, 
TABLE 1: Interpretation of Christian hospitality values in bancaan tradition.

Bancaan tradition
In bancaan, the host will extend their invitation to the
playmates to join them to celebrate their birthday with
gratitude.
Ubo rampe or the banquets are prepared with a sense of
simplicity and full of meaning. It has a unique point in which
every child cannot have their side dish (boiled egg) in whole
in their meal but instead gets one-eighth or one-sixteenth
part of it only.
Children are invited as a form of gratitude and regeneration
of hospitality values when they become adults. Bancaan
emphasises equality and is willing to accept and welcome
a husband with a simple birthday ceremony. This will be
carried as an eternal value when you grow up.

\section{Jesus blessing children}

Jesus accepted children coming to him and instead rebuked those who scolded them.

It is children whom Jesus declared will inherit the Kingem of Heaven, in correspondence with this saying, for to such belongs the kingdom of saying, ... for to such belongs the kingdom of (Mark 10:14, ESV). Jesus altogether received children coming to him with simplicity.

Jesus prayed and blessed the children to be like him who can accept and receive everyone.

\section{Hospitality values}

Values of openness in extending the invitation for every child to participate in expressing gratitude.

Simplicity in interaction with one another creates a strong familial feeling. This is because everything performed in the bancaan is simple, cheap and can be performed by the Javanese. It is like Jesus laying his hands on children. An action that is simple but meaningful.

Values of hospitality regeneration in bancaan in which children participate in a simple celebration internalised that they can internalise in their hearts and minds like Jesus who was willing to pray for them.

carried as an eternal value when you grow up.

Based on the analysis in Table 1, three sub-values of Christian hospitality contained in bancaan tradition can be inferred. These sub-values become the force of reinvigoration for the Christian contextual approach in bancaan.

(2) each person is a living creature, (3) each person needs one another and (4) each person is a wayfarer living because of God (Martin 2014:1). Based on these things, Christian hospitality should be practised by everyone as each human is a guest hosted first by Jesus.

Hospitality, according to Michelle Hershberger, is a form of friendship with strangers. The Bible records many instances of visitation from strangers, and all Biblical figures showed this kind of company. Hospitality makes strangers a part of the family by various means of cordiality given so that there are no strangers anymore. The Bible gives a clear picture that strangers become a particular part because of the Word of God (Hershberger 2009:13). Hospitality erases barriers separating one human from another. Through hospitality, each person treats others exceptionally well.

\section{Christian hospitality values in bancaan tradition}

Reinterpretation of bancaan as a tradition containing Christian hospitality values is analysed (Table 1).

Firstly, bancaan contains openness values in its inviting of every playmate of the child to attend the ceremony for expressing his or her gratitude. Playmates are all invited regardless of their religion, ethnicities and race. Predominantly, Javanese Muslims invite Christians and vice versa without mistrusts. All children are viewed as individuals and without being discriminated. The children are asked to sit together in a simple celebration to enjoy simple banquet (called ubo rampe). The ones holding this simple reception widely openly open their doors for these children. It corresponds to Christ, who opened his guard for children to come to him. Based on this study, one of the Javanese hospitality values can be shown by receiving every child regardless of their background without mistrusts.

Secondly, bancaan is full of simplicity in its interaction, which creates a robust familial feeling. Ubo rampe or the banquet has noble meanings hidden within it. The meals served are classified as easy to find and process that every Javanese family can hold the bancaan celebration. The value of simplicity is also present in the side dish of whole boiled egg that should be cut into $8-16$ pieces so that each child can have their equal share. It also corresponds to Jesus that, in simple ways, he wanted to accept children coming to him, as opposed to his disciples who scolded them instead. Jesus was impressed with the simplicity of children, and he gave an important lesson that hospitality values are not only provided to people of high status and importance but also their children. Simplicity is a key at present times in applying hospitality that avoids mistrusts. Simplicity is the essence and no guest can tell the host to reject any children.

Thirdly, bancaan incites the regeneration of hospitality values. The tradition enables children to attend a simple gettogether, and it is internalised that the children can internalise the importance of hospitality as the essence of the festival itself. The children can feel a friendly atmosphere as their early days will bring the values to their hearts and minds. Bancaan provides an educational character of hospitality for children. Children who joyfully participate in bancaan internalise the experience into their hearts and minds to treat others hospitably, even in a straightforward way. Bancaan tradition has the power to bring children to their own hospitality values in their future.

\section{Conclusion}

The researchers conclude that bancaan can be applied to Christians, especially those of today's Javanese descent, as a form of Christian hospitality. Christian hospitality in bancaan consists of three sub-values essential to preserve amidst the progress of the times. The three important values of bancaan are as follows: (1) openness for every child in nature, regardless of their background, (2) hospitable interaction in simplicity and (3) regeneration of hospitality values to today's children.

The researchers suggest that churches in Java should initiate bancaan for preservation at present times. Churches need to review the importance of hospitality values contained in bancaan practice. It is expected that Javanese churches can contextualisation of bancaan tradition so that, in the end, there can be found continually preserved Javanese hospitality values that make the face of Javanese Christians image of God's face in full hospitality.

\section{Acknowledgements}

Acknowledgements given to Institut Agama Kristen Negeri Toraja. Personally, the authors would like to thank Eunike Paramita and Febriani Upa. The authors also acknowledge 
support from Mr Joni Tapingku, Mr Frans P. Rumbi, Mr T. Haryono and Mr K. Soleman.

\section{Competing interests}

The authors declare that they have no financial or personal relationships that may have inappropriately influenced them in writing this article.

\section{Authors' contributions}

D.F.P. was responsible for conceptualisation, data collection and structuring the research. Y.K.S. was responsible for the writing and supervision of the manuscript.

\section{Ethical considerations}

This article followed all ethical standards for research without direct contact with human or animal subjects.

\section{Funding information}

This research received no specific grant from any funding agency in the public, commercial or not-for-profit sectors.

\section{Data availability}

Data sharing is not applicable to this article as no new data were created or analysed in this study.

\section{Disclaimer}

The views and opinions expressed in this article are those of the authors and do not necessarily reflect the official policy or position of any affiliated agency of the authors.

\section{References}

Adimihardja, K., 2011, Metode Penelitian Sosial: Suatu Teknik Penelitian Bidang Kesejahteraan Sosial Dan Ilmu Sosial Lainnya, Edisi ke-8, ed. J. Budhi, PT Remaja Rosdakarya Offset, Bandung.
Adriana, I., 2011, 'Neloni, mitoni atau tingkeban: (Perpaduan Antara Tradisi Jawa Dan Ritualitas Masyarakat Muslim)', KARSA 19(2), 238-247.

Clifford, G., 1983, Abangan,Santri,Priyayi Dalam Masyarakat Jawa, Pustaka Jaua, Jakarta.

Dokhi, M., Siagian, T.H., Sukim, W.I., Hadi, D.W. \& Sambodo, N., 2016, Analisis Kearifan Lokal Ditinjau Dari Keragaman Budaya, Pusat Data dan Statistik Pendidikan dan Kebudayaan, Kementrian Pendidikan dan Kebudayaan Republi Indonesia, Jakarta.

Green, J.B. \& Mcdonald, L.M., 2013, The world of the New Testament, cultural, social, and historical contexts, Baker Academic, Grand Rapids, MI.

Haryono, T., 2015, Introduksi Perjanjian Baru, Yayasan Gamaliel, Surakarta.

Haryono, T. \& Panuntun, D.F., 2019, 'Model Gaya Hidup Nazir Sebagai Refleksi Gaya Hidup Hedon Pengkotbah Pada Zaman Milenial', Evangelikal: Jurnal Teologi Injili Dan Pembinaan Warga Jemaat 3(2), 174-184. https://doi.org/10.46445/ejti.v3i2.146

Henry, M., 2000, Commentary on the whole bible volume V (Matthew to John) by publisher, vol. V, Christian Classics Ethereal Library, Grand Rapid, MI.

Hershberger, M., 2009, Hospitalitas Orang Asing: Teman Atau Ancaman, BPK Gunung Mulia, Jakarta.

Herwinesastra, 2019, 'Budaya Betangkant Anak Dalam Suku Dayak Keninjal Sebagai Upaya Kontektualisasi Kasih Allah', Evangelikal: Jurnal Teologi Injili dan Pembinaan Warga Jemaat 3(2), 199-206. https://doi.org/10.46445/ejti.v3i2.147

Lailiyah, N., Waryanti, E. \& Agan, S., 2018, 'Nilai Kearifan Lokal Dalam Memetri Weton (Hari Lahir) Di Kabupaten Nganjuk', Simki-Pedagogia 2(3), 1-13.

Martin, L.R., 2014, 'Old Testament foundations for Christian hospitality', Verbum et Ecclesia 35(1), 1-9. https://doi.org/10.4102/ve.v35i1.752

Melalatoa, M.J., 1995, Ensiklopedia Suku Bangsa Di Indonesia (Jilid A-K), Departemen Pendidikan dan Kebudayaan Republik Indonesia, Jakarta.

Miles, M.B., Huberman, A.M. \& Saldaña, J., 2014, Qualitative data analysis: A methods sourcebook, 3rd edn., Sage, Los Angeles, CA.

Panuntun, D.F., Tanduklangi, R., Adeng, M. \& Randalele, C.E., 2019, 'Model Ibadah Sekolah Minggu Kreatif-Interaktif Bagi Generasi Alfa Di Gereja Toraja', BIA: Jurnal Teologi Dan Pendidikan Kristen Kontekstual 2(2), 19-20. https://doi. org/10.34307/b.v2i2.113

Pradanta, S.W., Sudardi, B. \& Subiyantoro, S., 2015, 'Kajian Nilai-Nilai Budaya Jawa Dalam Tradisi Bancaaan Weton Di Kota Surakarta (Sebuah Kajian Simbolisme Dalam Budaya Jawa)', LINGUA: Jurnal Bahasa, Sastra, Dan Pengajarannya 12(2), 155-172. https://doi.org/10.30957/lingua.v12i2.25

Prasetyo, B. \& Trisyanti, U., 2018, 'Revolusi Industri 4.0 Dan Tantangan Perubahan Sosial', IPTEK: Journal of Proceedings Series (5), 22-27.

Safitri, R.Y., 2018, 'Persepsi Masyarakat Jawa Terhadap Tradisi Brokohan Di Desa Jepara Kecamatan Way Jepara Kabupaten Lampung Timur', Universitas Lampung, Bandar Lampung.

Samsuri, S., 2004, 'Yahudi Dalam Zionisme Dan Israel', Millah: Jurnal Studi Agama 3(2), a12. https://doi.org/10.20885/millah.vol2.iss2.art12

Sarwanto, S., 2013, 'Pembelajaran IPA Berbasis Budaya Jawa', in Prosiding: Seminar Nasional Fisika dan Pendidikan Fisika: 'Pembelajaran Sains Berbasis Kearifan Lokal', vol. 2, pp. 176-182.

Siswanto, K., 2017, 'Perjumpaan Injil Dan Tradisi Jawa Timuran Dalam Pelayanan Mis Kontekstual', Evangelikal: Jurnal Teologi Injili Dan Pembinaan Warga Jemaat 1(1), 61-66. https://doi.org/10.46445/ejti.v1i1.57

Susanta, Y.K., 2015, 'Hospitalitas Sebagai Upaya Mencegah Kekerasan dan Memelihara Kerukunan dalam Relasi Islam-Kristen Di Indonesia', Societas Dei 2(1), 281. https://doi.org/10.33550/sd.v2i1.62

Wijayanti, H. \& Nurwianti, F., 2010, 'Kekuatan Karakter Dan Kebahagiaan Pada Suku Jawa', Jurnal Psikologi 3(2), 114 